\title{
A Critical Appraisal of the Impact of Reading Culture on Secondary School Students' Learning of Oral English in Ilesa West Local Government Area of Osun State
}

\author{
Oribabor, O.A (Ph.D) \\ Institute of Education, Faculty of Education, Obafemi Awolowo University, Ile-Ife. \\ (bisioribabor2006@yahoo.com)
}

\section{Doi:10.5901/jesr.2014.v4n6p397}

\section{Abstract}

This research work examined students' reading culture and assessed the factors influencing their reading culture. It also established the link between reading culture and oral English learning and found out the position of teachers on the teaching of oral English. Questionnaire and interview were used to collect information from 30 senior secondary school students in llesa West Local Government Area. Findings showed that students reading habit was poor, a number of factors were responsible for students' poor reading culture. It also showed a relationship between reading culture and learning of Oral English. Findings also showed that many teachers do not pay attention to the teaching of oral English.

\section{Introduction}

English Language is an international language in the world which has claimed $80 \%$ of the total world population. That is why English plays a great role in the school system in Nigeria since it is a language of social, political and education communication. It is a medium of instruction in our school systems and main mode of communication in our daily lives. An aspect of English language that also promotes effective learning of the subject is reading. So, discussions in English language remain incomplete if they are non-inclusive of reading. The objectives of reading in English are many. Reading increases knowledge. It educates and entertains. It is also a means of improving our standard of English, either written or spoken (oral) in the society.

It is saddening to note nowadays that in Nigeria reading culture is deficient. This is because the general orientation has placed priority on other less important things. For instance, majority of the youth believe that reading does not bring quick money. People believe that education and reading is a long term project which does not yield immediate dividend but, if at all, future money. Youths find it difficult to wait for a long term to make fortune; and because they want immediate money through Machiavellian means they venture into politics, business, internet fraud that brings money quickly. With these, reading culture does not mean anything to many students nowadays. An examination of reading shows its significance. Reading involves series of systems like eye to eye movement, tracing, moving along with hands while reading. A poor reading habit therefore does not only affect proficiency in the English language and other subjects, it possibly affects the coordination of some body parts.

Reading is highly important in our educational policy. Without reading there cannot be good and positive technology. We cannot develop in science orientated culture. A society that does not have reading culture is not a developing society. Such society will remain stagnant not developing in the field of technological know - how. The impact of reading culture on oral and spoken English in our secondary schools have to be discussed critically our poor reading culture have definitely have the teaching of oral English in secondary schools.

People are not ready to read nowadays, instead they dabble into politics that could bring money quickly. Reading according to the Encylopidiea Britanicca is define as follows: Reading is a complex cognitive process of decoding symbols in order to construct or derive meaning. Wilkpedia in the free encyclopedia assess reading as a cognitive, use to decode symbols so as to know the meaing (semantic) of what we are looking for especially in the areas of vocabulary. The overview of reading skills, is an assessment of cognitive benefit of reading.

Why do we read- We read to improve our knowledge, to entertain ourselves, for pleasure, to know the history of different societies and ethnic group all over the world. We also read to enhance good spoken English.

What is phonology?. Phonology is the process whereby we speak English by world of month, verbally to assess our level of competency in oral English. Phonology and oral English are synonymous intertwine and interwoven, as they are the same. In learing Oral English, the objective of phonology is to teach our student to know how to speak English 
fluently in the society. Since English Language is a second language and not our mother tongue, we need to acquire the skill of spoken it effectively and efficiently. The areas of oral English acquisition includes tests of oral on consonant sounds, vowels, pure dipthong intonation, syllable, accents and pronunciation of sounds cummed transcrbing of English sound alphabet. The revelations have shown that our society does not have reading cultaure nowadays.

Instead people and students believed that reading haibt is along term project which does not bring money. Our youths have dabbled into politics that bring money easily nowadays. That is why Bamigbose 1976 12-13 behaved that people are worried by the problem most people in the country faced in reading habit and oral English. It advised that people should develop habit in reading of Novels, so as to enhance good spoken English. Our country Nigeria has 250 indigneous languages (our mother tongue) which make it difficult to understand the teaching of English languge, since our reading is poor, which promote also poor spoken English. Why did our students failed Oral English in WASSCE. The reasons includes poor reading habit, no reading culture nowadays, English in not our mother tongue, to study English is intterculian task since we canot pronounce it like the nature speakers. Our level of education is too low. $90 \%$ of our people are illiterate. $5 \%$ of Nigerian population are literates. Only $1 \%$ of the population can speak English language fluently. Adegbile (1999) attested that a child cannot learn most of the dementary facts or ideas unless he understands that the language in which these ideas are expressed. The level of competeancy of students in reading often determine wether he will pass oral English in WASSCE or not. In fact oral English have contributed to the mass failure of students in English Language in WASSCE and NECO.

\section{Statement of the Problem}

Since English languae is a compulsory and major subject in the Nigerian educational system, reading culture needs to be improved drastically, so that spoken of English (phonology) will be good. The earlier a direct link is created between reading and oral English, the better for students in the learning of the very important aspect of the subject. This becomes more important considering the unsatisfactory performance that students record in oral English year in year out in public examinations.

\section{Purpose of the Study}

The purpose of this research work is to examine the link between reading culture and oral English. The specific objectives of the study are therefore to

i. Examine students' reading culture

ii. Assess factors influencing their reading culture

iii. Establish the link between reading culture and oral English learning

iv. Find out the position of teachers on the teaching of oral English

\section{Research Questions}

1. What is the general reading habit of secondary school students;

2. What are the factors affecting reading culture in secondary;

3. How does reading culture relate to Oral English learning; and

4. what is the position of teachers on the teaching of oral English

\subsection{Significance of the Study}

The study is significant in that reading habit facilitates good spoken English so, the outcome of this study is hoped to develop in the teachers ability to enhance students' reading habit so as to improve learning of oral English.

\subsection{Delimitation of the Study}

The research is based on the critical apprassal of the impact of reading culture on oral English teaching in some secondary schools in Ilesa West Local Government Area. The schools used for data collection included llesa High school, Hope High school, and George Burton College all in llesa. 


\section{Methodology}

They population for the study consisted of senior secondary school students in Osun State of Nigeria. The study sample comprise 30 senior secondary school three students selected from three schools in llesa. Copies of questionnaire were administered to collect information from the students. Guided interview and discussion were also held with the teachers to gather data on students' level of reading habit and their oral English learning status.

\section{Results and Discussion}

\subsection{Research question1}

What is the general reading habit of secondary school students;

This question was raised to determine the prevalent reading habit of students in secondary schools. Information gathered revealed that the existing reading habit of students is poor. This is informed by the position of students that you only read only when is it critically needed.

\subsection{Research question2}

What are the factors affecting reading culture in secondary

This research question sought to collection information on why the students' reading culture was that poor. Results showed that factors that influence poor reading culture include
a. laziness
b. lack of intrinsic motivation
c. lack of perseverance
d. poor requisite academic ability

\subsection{Research question 3}

How does reading culture relate to Oral English learning

Data on this research question were obtained from the questionnaire administered on the students. The questionnaire contained items that sought to know the students' perception of the link between their reading culture and their learning of oral English.

Table 3: Summary of students' responses on how reading culture is related to oral English

\begin{tabular}{|c|c|c|c|c|c|}
\hline S/N0 & Item & SA & A & SD & $\mathrm{D}$ \\
\hline 1 & Student love reading & & & 10 & \\
\hline 2 & Students hates reading & & & 08 & \\
\hline 3 & Orietation of people hate reading habits & & 08 & & \\
\hline 4 & Orientation of people loves reading habit & & 07 & & \\
\hline 5 & Teachers loves oral English to teach & & & 06 & \\
\hline 6 & Teachers hate to teach oral English in school & & 11 & & \\
\hline 7 & Reading habit aids good spoken English & & 10 & & \\
\hline 8 & Each school should have language labortary & 1 & 10 & 1 & 05 \\
\hline 9 & Language laboratory does not aid oral English & 1 & 2 & 1 & 09 \\
\hline 10 & Teachers are the major determinant of reading in school & 10 & 1 & & \\
\hline 11 & Teachers have no relevant in the teaching of oral & 2 & 1 & 06 & \\
\hline 12 & Teachers of English to form the literary and debating society in schools & 1 & 06 & 02 & 4 \\
\hline 13 & Parents should contribute to reading habit & 1 & 1 & 07 & 2 \\
\hline 14 & Nigerian youths does not have reading habits & 1 & 1 & 4 & 09 \\
\hline 15 & Societies does not favour reading culture & 1 & 1 & 2 & 10 \\
\hline 16 & Oral English is difficult to teach in schools & 2 & 6 & 2 & 5 \\
\hline 17 & Teacher does not pay attention to the teaching of Oral English any more & 4 & 2 & 2 & 8 \\
\hline 18 & English is difficult to teach because it as not our mother tongue & 04 & 05 & 2 & 07 \\
\hline 19 & We should speak like the Natives of England & 06 & 4 & 5 & 2 \\
\hline 20 & English is difficult to teach in schools & 2 & 5 & 6 & 2 \\
\hline
\end{tabular}




\subsection{Research question 4}

What is the position of teachers on the teaching of oral English

Teachers' responses reveal that students do not pay attention to oral English. Many teachers of English even do not care to teach oral English. That is why spoken English is highly deficient in Nigeria when compare with countries like Ghana and South Africa. When interviewing the teachers, they opined that they don't have time for the teaching of oral English. Some teachers even believe that oral English is too simple and there is nothing to teach there. It is the simplicity of the subject oral English that make student to fail the 60 objective questions on oral English which often leads to mass failure of English language in WASSCE and NECO.

Teachers confessed that they pay more attention to the teaching of Grammar, Essays and Summary writing which, carried high marks, without minding that test of oral is equally good, to make students pass very well in English language in the final Examination.

\section{Conclusion}

The quality of instruction has significant relatinship on reading habit impact on tests of orals in our secondary schools. Relatioinshiup between instructional materials and students level of performance of tests of orals is highly significant. It is summarily noted that if there are adequate languagte laboratory, with radios to test orals, with good reading habits students will definitely make it in spoken English.

Teachers who do not pay any attention to oral English and reading habits have been contributing to the failure of students in oral English.

In an attempt to assist the secondary school students improve on their reading habit to have good impact on the test of orals in English Language, it is important to have careerists to guide students to develop interest in reading habit and how to speak English Language fluently in the school through the constant use of literary and debating society, which involve arguments, speech making and quizz competitions. This will enhance good reading habit to have in turn good performance in the test of orals and spoken English in our secondary schools.

\section{Recommendations}

Based on the findings of this study, the following recommendations are made

i. Teachers to develop interst in the test of oral English.

ii. Teachers to form reading club, so as to enhance good reading habit.

iii. The school management is to form the literacy and debating society to promote spoken English.

iv. Teachers are to monitor the students activities even to make then speak English very well in the school.

v. Parents are to monitor their wards and students to speak English very well after the school hours

\section{References}

Ayodele J.B (1981) A study of some factors related to reading problem among Nigeria Adolescent JES. Vol 2. P. 102 Ayodele S.O (2002). The use of English in reading. Haneman publication Ltd

ANAP. P.O (2009). Problem of speaking English in Nigeria as a second language. London Publishers.

Adenuga, S. (2009). Why students fail Oral English. Ibadan :Macmillan Ltd.

Adenuga, S. (2009). Why reading habit is low in Nigeria. Ibadan: Macimillan Ltd.

Adenuga, S. (2009). Changing of orientation of reading habit to make quick money in politics, Ibadan: Macmillan Ltd., 